\title{
MODEL PEMBELAJARAN KOOPERATIF TIPE PAIR CHECK UNTUK MEMBANGUN KETERAMPILAN BERTANYA PRODUKTIF SISWA
}

\author{
Dwi Ermavianti, Wahyu Sulistyorini \\ SMK Negeri 1 Sewon \\ Email: ermasuharson@gmail.com
}

\begin{abstract}
This study aimed for (1) developing the students' productive questioning ability in the subject of Anatomy and Physiology and (2) improving the students' productive cognitive learning. This classroom action study was conducted for the X grade students of the Department of Make up and Beauty Teraphy II. It was undertaken during the odd semester of the academic year of 2014/2015. The data was collected by participatory monitoring, questionnaires, and documentary study. The data resulted from the observation, the interviews, and the discussions with collaborators were analysed, identified, interpreted, validated, and inferred descriptively. The results revealed the students' productive questioning ability development in the subject of Anatomy consists of 9 stages: the concept explanation, groups division, texts distribution, pair-check assignments, role shifts, answers validation, counseling and directing, correct answers validation, and rewards distribution. In the preliminary condition, the students' questioning ability was scored and categorised as fair. In the second cycle, it achieved higher score and was categorised as good. It was proved by the higher frequency of questions and the more productive reading ability of the students. The students' performance in the first cycle that was categorised as good and very good were $61.3 \%$ and $9.67 \%$ respectively. While in the second cycle, 12 students with the percentage of $38.70 \%$ were categorised as good and 15 students with the percentage of $48.30 \%$ were categorised as very good in productive questioning.
\end{abstract}

Key words: cooperative learning model, pair check type, productive questioning ability

\section{ABSTRAK}

Penelitian ini bertujuan untuk (1) membangun keterampilan bertanya produktif siswa pada mata pelajaran anatomi dan fisiologi dan (2) mengembangkan cara berpikir siswa agar terampil secara produktif. Penelitian ini menggunakan disain Penelitian Tindakan Kelas, dengan setting kegiatan pembelajaran dilaksanakan pada semester ganjil bagi siswa kelas X Tata Kecantikan 2 tahun ajaran 2014/2015. Teknik pengumpulan data menggunakan pemantauan partisipatif, kuisioner, dan studi dokumentasi. Data hasil pengamatan, wawancara, diskusi dengan kolaborator dan dokumen dianalisis secara deskriptif, identifikasi, interprestasi, validasi dan inferensi. Hasil dari penelitian adalah membangun keterampilan bertanya produktif siswa pada mata pelajaran anatomi terdapat 9 tahapan antara lain: menjelaskan konsep, membagi siswa dalam kelompok, membagikan teks, melaksanakan pair check, siswa bertukar peran, mencocokkan jawaban, membimbing dan mengarahkan, mengecek jawaban benar, dan mendapatkan reward. Kondisi awal yang menunjukkan siswa ketika mengungkapkan pertanyaan secara singkat dan jelas memperoleh kriteria cukup. Pada akhir kegiatan (siklus 2) mengalami peningkatan memperoleh kriteria baik. Hal ini terlihat dari frekwensi siswa dalam bertanya mengalami peningkatan, dan mampu membaca secara produktif sesuai dengan teks/bacaan yang diberikan oleh guru. Indikator kinerja di siklus 1 memperoleh kriteria baik $(61,3 \%)$ dan kriteria sangat baik $(9,67 \%)$. Pada siklus 2 sebanyak 12 orang $(38,70 \%)$ siswa memperoleh predikat baik, dan sebanyak 15 orang $(48,30 \%)$ memperoleh predikat sangat baik dalam bertanya produktif.

Kata kunci: keterampilan bertanya produktif, model pembelajaran kooperatif, tipe pair check

\section{PENDAHULUAN}

Sebagai upaya untuk mewujudkan pembelajaran yang menyenangkan, kreatif dan inovatif guru senantiasa mengembangkan dan mengimplementasikan berbagai model pembelajaran yang mendukung terciptanya suasana yang nyaman di kelas. Berdasarkan hasil observasi selama 1 semester di kelas X Tata Kecantikan 2 dalam mata pelajaran 
Anatomi dan Fisiologi, guru mengamati beberapa kendala dalam pembelajaran di kelas, antara lain: (1) pembelajaran dengan sistem ceramah, siswa bosan sehingga sering berbicara sendiri, (2) siswa hanya sebagian saja yang aktif dan terlihat antusias jika dilaksanakan diskusi dalam kelas, (3) siswa tidak fokus atau konsentrasi ketika membaca materi yang diberikan guru, (4) siswa jarang atau bahkan hampir tidak pernah mengajukan pertanyaan pada guru atau teman yang berkaitan dengan materi, (5) cenderung acuh tak acuh dan mengabaikan jawaban atas pertanyaan yang diberikan guru, (6) siswa bekerjasama dalam menjawab pertanyaan dari materi pembelajaran dan cenderung bergantung pada teman yang lebih menguasai, (7) siswa belum dapat membuat rangkuman dengan bahasa sendiri, (8) belum terbiasa melontarkan pertanyaan antar anggota kelompok maupun ke kelompok lain, (9) siswa belum terbiasa menggali informasi melalui kegiatan bertanya, (10) guru belum mengembangkan pertanyaan yang bermutu untuk melatih siswa dalam berpikir kritis. Pembelajaran selama satu semester yang telah dilakukan kurang berpusat pada siswa, hal ini ditandai dengan sedikit sekali siswa yang mengajukan pertanyaan pada setiap pertemuan.

Usaha untuk mengatasi masalah tersebut guru mengimplementasi model pembelajaran yang mampu mengkonstruksi pengetahuan siswa melalui keterampilan bertanya. Inovasi pembelajaran ini akan merubah paradigma lama menjadi paradigma baru dimana pendekatan pembelajaran dapat mengembangkan dan menggali pengetahuan siswa secara konkrit dan mandiri, terutama dalam menggali pengetahuan dengan kegiatan bertanya. Model pembelajaran yang dapat diterapkan di kelas untuk mengatasi permasalahan tersebut yaitu pembelajaran kooperatif model pair check pada mata pelajaran anatomi dan fisiologi. Pembelajaran pair check merupakan pembelajaran kelompok terdiri dari dua orang atau perpasangan, satu orang berperan sebagai pelatih dan yang lain berperan sebagai partner (Huda, 2013). Siswa dituntut untuk mandiri dan memiliki kemampuan dalam menyelesaikan persoalan, serta melatih tanggung jawab sosial, kerjasama, dan memberikan penilaian. Melalui pair check, siswa akan berlatih memahami suatu bacaan dengan cara tanya jawab. Siswa diharapkan akan memahami isi suatu teks atau bacaan secara seksama. Paper ini menyajikan model pembelajaran kooperatif tipe pair check untuk membangun keterampilan bertanya.

\section{METODE}

Prosedur penelitian ini menggunakan desain Penelitian Tindakan Kelas (PTK), yang pelaksanaannya meliputi 4 tahap sebagai acuan dalam proses pembelajaran yaitu: Perencanaan (planning), pelaksanaan (action), pengamatan (observation), refleksi (reflection). Secara operasional kegiatan guru dan siswa selama proses pembelajaran menggunakan model pembelajaran kooperatif tipe pair check. Penelitian ini dilaksanakan selama 2 siklus dengan 3 kali pertemuan pada tiap siklusnya. Pada siklus pertama materi yang disampaikan adalah pokok bahasan susunan kerangka tubuh manusia pada kelas $\mathrm{X}$ Tata Kecantikan 2 dengan durasi waktu $3 \times 45$ menit. Sesuai dengan kondisi di awal sebelum pelaksanaan tindakan siswa jarang atau bahkan hampir tidak pernah mengajukan pertanyaan pada guru atau teman yang berkaitan dengan materi, sering berbicara sendiri dan sebagian saja yang berani bertanya atau menyampaikan pendapat ketika berdiskusi.

Langkah pertama dalam penelitian adalah perencanaan (Planning) meliputi (1) Membuat instrumen pembelajaran yang terdiri dari Rencana Pelaksanaan Pelajaran (RPP) dan skenario pembelajaran; (2) Membuat instrumen untuk mengamati aktivitas guru dan siswa dengan Lembar Observasi Guru (LOG) dan Lembar Observasi Siswa (LOS) dalam proses pembelajaran pair check; (3) Menyiapkan media dan sarana pembelajaran yang di perlukan; (4) Menyiapkan lembar penilaian implementasi strategi pembelajaran pair check; 
(5) Sesuai dengan strategi pembelajaran pair check maka untuk panduan dalam menyusun instrumen, lembar pengamatan untuk guru dan siswa, serta RPP mengikuti tahapan pada Tabel 1.

Tabel 1. Langkah Pembelajaran Model Kooperatif Tipe Pair Check

\begin{tabular}{|c|c|c|c|}
\hline No & Langkah-langkah Pembelajaran & Kegiatan Guru & Kegiatan Siswa \\
\hline 1 & Menjelaskan konsep & $\begin{array}{l}\text { Guru menjelaskan tujuan } \\
\text { pembelajaran dan materi yang akan } \\
\text { disampaikan }\end{array}$ & $\begin{array}{l}\text { Siswa memperhatikan keterangan } \\
\text { guru }\end{array}$ \\
\hline 2 & $\begin{array}{l}\text { Membagi siswa dalam } \\
\text { kelompok }\end{array}$ & $\begin{array}{l}\text { Guru mengarahkan siswa untuk } \\
\text { membagi diri dalam kelompok, } \\
\text { dan menentukan siapa yang akan } \\
\text { berperan sebagai pelatih atau } \\
\text { partner }\end{array}$ & $\begin{array}{l}\text { Siswa membagi diri dalam } \\
\text { kelompok, dan menentukan siapa } \\
\text { yang akan menjadi pelatih atau } \\
\text { partner }\end{array}$ \\
\hline 3 & Membagikan teks (bacaan) & $\begin{array}{l}\text { Guru membagikan teks (bacaan) } \\
\text { kepada siswa }\end{array}$ & $\begin{array}{l}\text { Siswa membaca secara produktif } \\
\text { teks (bacaan) yang diberikan guru }\end{array}$ \\
\hline 4 & $\begin{array}{l}\text { Melaksanakan kegiatan } \\
\text { pembelajaran kooperatif tipe } \\
\text { pair check }\end{array}$ & $\begin{array}{l}\text { Guru memberikan kesempatan } \\
\text { kepada siswa yang berperan } \\
\text { sebagai pelatih untuk mengajukan } \\
\text { pertanyaan kepada partner }\end{array}$ & $\begin{array}{l}\text { Siswa yang berperan sebagai } \\
\text { pelatih menyusun pertanyaan dan } \\
\text { membuat kunci jawaban. Siswa } \\
\text { yang bertugas sebagai pertner } \\
\text { menjawab pertanyaan dari pelatih }\end{array}$ \\
\hline 5 & $\begin{array}{l}\text { Pelatih dan partner saling } \\
\text { bertukar peran. Pelatih menjadi } \\
\text { partner, dan partner menjadi } \\
\text { pelatih }\end{array}$ & $\begin{array}{l}\text { Guru mengarahkan siswa untuk } \\
\text { bertukar peran }\end{array}$ & Siswa bertukar peran \\
\hline 6 & $\begin{array}{l}\text { Setiap pasangan kembali ke tim } \\
\text { awal dan mencocokan jawaban } \\
\text { satu dengan yang lainnya }\end{array}$ & $\begin{array}{l}\text { Guru meneliti hasil pekerjaan } \\
\text { siswa }\end{array}$ & $\begin{array}{l}\text { Siswa mengumpulkan hasil } \\
\text { pertanyaan dan jawaban }\end{array}$ \\
\hline 7 & $\begin{array}{l}\text { Membimbing dan memberikan } \\
\text { arahan atas jawaban dari } \\
\text { berbagai soal }\end{array}$ & $\begin{array}{l}\text { Guru membimbing dan } \\
\text { memberikan arahan atas } \\
\text { pertanyaan dan jawaban dari siswa }\end{array}$ & $\begin{array}{l}\text { Siswa mencatat dan } \\
\text { mendengarkan penjelasan guru }\end{array}$ \\
\hline 8 & $\begin{array}{l}\text { Setiap tim mengecek } \\
\text { jawabannya }\end{array}$ & Guru mengevaluasi & $\begin{array}{l}\text { Siswa mencatat dan } \\
\text { mendengarkan penjelasan guru }\end{array}$ \\
\hline 9 & $\begin{array}{l}\text { Tim yang paling banyak } \\
\text { mendapat kupon diberi hadiah } \\
\text { atau reward oleh guru }\end{array}$ & Guru memberikan nilai & $\begin{array}{l}\text { Siswa melaporkan hasil kepada } \\
\text { guru }\end{array}$ \\
\hline
\end{tabular}

Langkah kedua adalah pelaksanaan (acting). Secara umum kegiatan pelaksanaan terdiri dari; kegiatan pendahuluan meliputi (1) Mengucapkan salam dengan ramah kepada siswa ketika memasuki ruangan: (2) Memeriksa kehadiran siswa; (3) Memeriksa kesiapan siswa untuk mengikuti pembelajaran; (4) Mengajukan pertanyaan yang mengaitkan pengetahuan sebelumnya dengan materi yang akan dipelajari; (5) Menjelaskan tujuan pembelajaran atau kompetensi dasar; (6) Menyampaikan cakupan materi yang akan dipelajari; (7) Mempersiapkan materi pembelajaran beserta alat atau media pembelajaran.

Kemudian kegiatan inti meliputi (1) Guru menjelaskan model pembelajaran yang akan dilaksanakan kepada siswa; (2) Siswa dibagi ke dalam beberapa tim, setiap tim terdiri dari 4 orang. Dalam satu tim ada 2 pasangan. Setiap pasangan dalam satu tim dibebani masingmasing satu peran yang berbeda: pelatih dan partner, (3) Guru membagikan teks (materi) kepada siswa (yang berperan sebagai partner), (4) Guru memberi kesempatan kepada siswa mengkaji bacaan teks, secara mandiri; (5) Guru memberikan kesempatan kepada siswa yang berperan sebagai pelatih agar mengajukan pertanyaan-pertanyaan tentang isi bacaan teks kepada partner, dan pelatih agar mengecek jawaban partner; (6) Guru memberikan kesempatan kepada pasangan bertukar peran dan melakukan hal yang sama; (7) Guru membimbing dan memberikan arahan atas pertanyaan produktif dan jawaban dari siswa; 
(8) Setiap tim memeriksa jawaban; (9) Tim yang paling banyak mendapat kupon diberi hadiah atau reward oleh guru dan kegiatan terakhir adalah penutup meliputi (1) Membuat kesimpulan bersama siswa; (2) Mengevaluasi indikator yang akan dicapai; (3) Memberikan tugas kepada siswa.

Langkah ketiga dalam penelitian adalah pengamatan (observation). Kegiatan dalam pengamatan dilakukan oleh guru bersama kolaborator untuk menilai aktivitas guru dan siswa selama kegiatan pembelajaran berlangsung dalam tim. Siswa diberikan kesempatan untuk menilai pasangannya (peer assessment) pada lembar observasi. Kegiatan yang dilakukan pada tahap ini adalah menerapkan instrumen observasi yang telah disusun dalam tahap perencanaan meliputi: (1) Melakukan observasi terhadap guru pada waktu melaksanakan model pembelajaran kooperatif tipe pair check; (2) Melakukan observasi terhadap siswa pada saat melaksanakan model pembelajaran kooperatif tipe pair check; (3) Mencatat kejadian penting selama kegiatan model pembelajaran kooperatif tipe pair check.

Langkah keempat adalah refleksi yang dilakukan dengan cara mendiskusikan masalah dalam kelas penelitian dan ditentukan setelah adanya implementasi strategi pembelajaran pair check. Antara lain dengan mengumpulkan hasil yang diperoleh pada pengamatan aktivitas guru dan siswa selama pembelajaran berlangsung. Pada siklus I pertemuan kedua akan dianalisis untuk mengetahui kekurangan atau kelemahan pembelajaran yang dilakukan. Hasil analisis tahap I diperbaiki di siklus II sehingga pembelajaran siklus II diharapkan dapat lebih baik. Apabila masalah di kelas sudah teratasi, maka siklus PTK dapat diakhiri.

Adapun setting penelitian ini adalah kelas $\mathrm{X}$ (sepuluh) Tata kecantikan 2. Waktu kegiatan dilaksanakan pada bulan Januari sampai dengan Maret 2015 yang diintergrasikan dalam proses belajar mengajar. Materi yang disampaikan adalah mata pelajaran Anatomi dan Fisiologi pokok bahasan unit 4 yaitu susunan kerangka tubuh manusia. Adapun indikator kinerja yang akan dicapai dari penelitian ini adalah: (1) Sebesar $70 \%$ dari jumlah siswa di kelas $\mathrm{X}$ TK 2 terampil bertanya produktif pada pokok bahasan susunan kerangka tubuh manusia di siklus I, (2) Pada siklus II sebesar $80 \%$ dari jumlah siswa di kelas terampil bertanya produktif pada pokok bahasan susunan kerangka tubuh manusia.

Nurhadi dan Senduk (2003) menjelaskan pembelajaran kooperatif adalah pembelajaran yang secara sadar menciptakan interaksi yang silih asah sehingga sumber belajar bagi siswa bukan hanya guru dan buku ajar, tetapi juga sesama siswa. Lie (2002) memaparkan bahwa pembelajaran kooperatif adalah sistem pembelajaran yang memberi kesempatan kepada siswa untuk bekerjasama dengan sesama siswa dalam tugas-tugas yang terstruktur, dan dalam sistem ini guru bertindak sebagai fasilitator. Model pair check merupakan metode pembelajaran berkelompok antara dua orang atau berpasangan yang dipopulerkan oleh Spencer Kagan pada tahun 1990. Model ini menerapkan pembelajaran kooperatif yang menuntut kemandirian dan kemampuan siswa dalam menyelesaikan persoalan. Metode ini juga melatih tanggung jawab sosial siswa, kerja sama, dan kemampuan memberi penilaian. Secara umum sintak pembelajaran pair check adalah (1) bekerja berpasangan; (2) pembagian peran partner dan pelatih; (3) pelatih memberi soal, partner menjawab; (4) pengecekan jawaban; (4) bertukar peran; (5) penyimpulan; (6) evaluasi. Tipe pair check memiliki kelebihan tersendiri, yaitu: (1) meningkatkan kerjasama antar siswa (2) peer tutoring; (3) meningkatkan pemahaman atau konsep dan atau proses pembelajaran; (4) melatih siswa untuk berkomunikasi dengan baik sesama teman sebangku. Sementara itu metode ini juga memiliki kekurangan utama karena metode tersebut membutuhkan (1) waktu yang lama atau cukup memadai; (2) kesiapan siswa untuk menjadi pelatih atau partner yang jujur dan memahami soal dengan baik (Huda, 2013).

Depdiknas (2003: 23) mendefinisikan pertanyaan produktif sebagai pertanyaan yang 
hanya dapat dijawab melalui pengamatan, percobaan, atau penyelidikan. Pengamatan dapat berupa melakukan kajian teks. Membaca dengan kritis sangat erat kaitannya dengan berpikir kritis. Zaleha (2004: 96) menjelaskan beberapa langkah yang harus dikuasai untuk membaca dengan kritis antara lain: (1) amati dan baca sekilas sebuah teks sebelum membaca keseluruhan, (2) hubungkan teks dengan konteksnya, yaitu dengan meletakkan pada konteks yang betul, (3) buat pertanyaan tentang kandungan teks saat membaca, (4) refleksikan kandungan teks yang berhubungan dengan pendapat sendiri, (5) buat ringkasan kandungan teks dengan menggunakan kata-kata sendiri, (6) evaluasi teks dari segi logika, kredibilitas, dan reliabilitasnya, (7) bandingkan teks yang dibaca dengan teks lain dalam hal persamaan dan perbedaan.

\section{HASIL DAN PEMBAHASAN}

Pada tahap perencanaan di siklus 1 dengan mengimplementasikan model pair check, guru menyusun perencanaan sebagai berikut: (1) Menganalisis KI-KD untuk melaksanakan tatap muka pembelajaran; (2) Merancang skenario pembelajaran model kooperatif tipe pair check; (3) Menyusun RPP model pembelajaran kooperatif tipe pair check; (4) Membuat instrumen untuk mengamati aktivitas guru, dan aktivitas siswa dalam melaksanakan pembelajaran serta mengamati keterampilan siswa dalam bertanya produktif; (5) Membuat media pembelajaran dalam bentuk power point, dan teks (bacaan) untuk siswa; (6) Menyusun alat evaluasi untuk mengukur keterampilan bertanya produktif setiap akhir siklus.

Pembelajaran di siklus 1 pertemuan pertama, kedua, dan ketiga guru melaksanakan pembelajaran dengan materi pokok bahasan susunan kerangka tubuh manusia. Adapun langkah-langkahnya adalah sebagai berikut: Pendahuluan (kegiatan awal), pada pertemuan pertama guru mengucapkan salam dan membuka pelajaran dengan berdoa. Guru memeriksa kehadiran siswa, dan menyampaikan tujuan pembelajaran yang ingin dicapai yaitu siswa dapat menjelaskan pokok bahasan susunan kerangka tubuh manusia. Guru memotivasi siswa dengan menceritakan tentang kondisi tubuh manusia melalui power point. Selanjutnya guru memberikan informasi tentang kegiatan yang akan dilakukan pada hari ini.

Pada kegiatan inti di siklus pertama ini guru melakukan kegiatan pembelajaran melalui beberapa tahap antara lain; (1) Sebelum berpasangan dalam model pair check, siswa diajarkan memahami teks. Hal ini bertujuan untuk mengarahkan siswa dalam membuat pertanyaan produktif; (2) Guru membagikan teks atau materi pelajaran, kemudian memandu siswa untuk membaca secara produktif dengan menggarisbawahi kalimat yang penting atau memberikan tanda merah pada intisari dari materi yang diberikan. Pada pertemuan ini yang disampaikan adalah pokok bahasan kerangka tubuh manusia; (3) Guru membagi siswa dalam kelompok, dan berpasang-pasangan. Setiap pasangan dibebaskan untuk memilih hendak menjadi pelatih atau partner terlebih dahulu; (4) Selanjutnya siswa yang bertugas menjadi pelatih yang mendapat kesempatan pertama membuat pertanyaan produktif yang nanti akan dijawab oleh partner. Jumlah pertanyaan yang dibuat minimal 2 dan mengacu pada teks yang sudah ada; (5) Siswa yang berperan sebagai partner menjawab pertanyaan yang diberikan oleh pelatih, dilanjutkan pelatih mengoreksi jawaban benar; (6) Selanjutnya pasangan bertukar peran; (7) Setelah seluruh pasangan dalam kelompok menyelesaikan pekerjaannya dalam membuat pertanyaan produktif dan menjawab, maka guru memberikan poin berupa nilai kepada siswa. Dilanjutkan dengan evaluasi kegiatan yang telah dilaksanakan dan ketercapaian materi pembelajaran pada pertemuan ini. Setelah selesai pembelajaran guru melakukan kegiatan penutup dengan membahas dan menyimpulkan kegiatan yang telah dilakukan.

Pada pertemuan di siklus 1 siswa belum maksimal dalam memahami cara membaca produktif dan memahami bacaan. Sehingga 
masih timbul kesulitan dalam membuat pertanyaan. Guru memberikan evaluasi dan memberikan tugas kepada siswa. Pada akhir pertemuan siklus 1 beberapa siswa yang dianggap guru mampu membaca dan memahami teks atau bacaan secara produktif maka diberi kesempatan untuk mendampingi dan berpasangan dengan temannya pada pertemuan berikutnya dengan model pair check.

Hasil observasi atau monitoring tindakan guru pada penerapan model pembelajaran pair check menunjukan secara umum aktivitas guru memiliki beberapa kelebihan antara lain: dalam menjelaskan konsep, memberikan arahan pada siswa sudah terlaksana dengan baik. Guru juga menjelaskan kepada siswa teknik membaca produktif pada teks atau bacaan yang tengah dipelajari. Guru memberikan poin dan reward berupa nilai kepada siswa. Pada sisi kelemahan aktivitas guru adalah dalam menjelaskan model pair check kurang jelas, sehingga sebagian besar siswa belum mengerti yang menimbulkan banyak pertanyaan, terutama dalam hal membaca secara produktif dan membuat pertanyaan produktif. Hasil pengamatan oleh kolaborator menunjukan bahwa masih terdapat beberapa kekurangan antara lain: pada saat guru menjelaskan tentang cara bermain pembelajaran model pair check sebagian murid ternyata belum mengerti dengan benar bahwa tugas pelatih memberikan pertanyaan, dan partner menjawab sesuai isi bacaan, sehingga masih banyak siswa yang bertanya dan tidak paham akan hal tersebut. Guru sudah melaksanakan tetapi, masih banyak siswa yang belum mengerti, sehingga timbul pertanyaan tentang cara bermain model pair check. Ketika di akhir pembelajaran guru lupa untuk memberikan kesimpulan, guru juga belum memberikan evaluasi tentang pertanyaan produktif yang telah dikerjakan siswa, selain itu guru juga belum melaksanakan tanya jawab pada siswa.

Sedangkan dalam observasi aktivitas siswa ada 3 aktivitas yang diamati, yaitu (1) keterlaksanaan siswa dalam implementasi model pair check, (2) pengamatan terhadap keterampilan bertanya produktif siswa, (3) tingkatan kognitif dari pertanyaan yang muncul dalam pembelajaran model pair check ini. Secara umum dalam mengamati keterlaksanaan siswa dalam implementasi model pair check ini siswa tidak mengalami kesulitan. Siswa mengikuti petunjuk yang telah disampaikan guru melalui power point, dengan mencari pasangan dan membagi peran dalam kegiatan.

Selanjutnya dalam mengamati keterampilan bertanya produktif siswa, ada enam komponen yang diamati. Pada kegiatan siswa ketika mengungkapkan pertanyaan secara jelas dan singkat memperoleh skor sebesar 1,77 hal ini masuk dalam kriteria cukup. Siswa dalam mengungkapkan pertanyaan masih kurang jelas terlihat dari pertanyaan yang disampaikan secara lisan dan tertulis terdapat banyak kesamaan dengan pasangan. Komponen kedua yaitu pertanyaan berdasarkan acuan kegiatan atau bacaan memperoleh skor sebesar 1,75 dalam kegiatan membaca secara produktif siswa juga masuk dalam kategori cukup, terutama dalam memahami teks bacaan dalam setiap pembelajaran. Komponen yang ketiga yaitu memberikan kesempatan teman untuk berfikir memperoleh skor sebesar 1,95 masuk dalam kategori cukup, siswa sering meminta teman untuk menjawab pertanyaan lebih cepat dibanding mencari jawaban benar ketika sedang menjawab pertanyaan yang diajukan pasangan.

Komponen yang keempat ada dua yaitu (1) pertanyaan produktif yang didasari kegiatan bacaan mendapatkan skor sebesar 1,6 dalam hal ini siswa masih belum memahami inti teks atau bacaan yang diberikan guru untuk dapat bertanya secara produktif. Siswa cenderung membaca hanya sepintas tanpa memahami atau mengingat teks yang dibaca tersebut. Siswa belum mengetahui sepenuhnya bahwa kegiatan membaca produktif juga akan menghasilkan pertanyaan produktif juga, (2) pertanyaan bermutu yang memunculkan beberapa alternatif jawaban memperoleh skor sebesar 1,45 hal ini masuk dalam kategori cukup, dalam bertanya siswa hasil yang dimunculkan adalah siswa lebih banyak masuk dalam ranah memahami (menyebutkan, menjelaskan). Jenis pertanyaan 
dalam ranah tersebut tidak akan memerlukan jawaban panjang. Pada komponen kelima yaitu pengungkapan tertulis secara tingkatan kognitif diperoleh skor sebesar 1,77 dalam kegiatan ini siswa masih dalam tahap mampu memahami teks atau bacaan tetapi belum sampai memahami, dan menerapkan. Pada saat siswa melakukan tanya jawab dengan teman menggunakan model pair check, guru meminta siswa untuk menuliskan pertanyaan yang sudah disampaikan. Hal ini dimaksudkan untuk mempermudah guru dalam mengelompokkan pertanyaan siswa ke dalam 6 tingkatan kawasan kognitif.

Jika dalam setiap siklusnya masingmasing siswa mengemukakan pertanyaan sebanyak 3 kali dalam setiap pertemuan, maka siswa akan bertanya sebanyak 9 kali. Sehingga pertanyaan yang akan muncul dalam siklus 1 sejumlah 279 kali. Dalam pembelajaran siklus 1 , pertanyaan yang ada dalam tingkatan kognitif mengingat terdapat 49 pertanyaan atau sebesar $30,2 \%$ dari seluruh pertanyaan yang muncul. Pada tingkatan kognitif memahami diperoleh 81 pertanyaan atau sebesar 49,6\%. Sedangkan pada tingkatan kognitif mengaplikasi diperoleh sebanyak 33 pertanyaan yang muncul atau sebesar 20,2\%. Dengan demikian jumlah pertanyaan produktif yang muncul dari siswa pada siklus 1 termasuk dalam kategori baik.

Berdasarkan hasil analisis perolehan keterampilan bertanya produktif siswa dapat diperoleh kesimpulan bahwa dalam mengamati keterampilan bertanya produktif siswa diperoleh hasil sebagai berikut: sebanyak $6,45 \%$ (2 siswa) memperoleh predikat sangat kurang dalam keterampilan bertanya. Sebanyak 22,5\% (7 siswa) memperoleh predikat kurang dalam keterampilan bertanya. Selanjutnya sebesar 61,3\% (19 siswa) memperoleh predikat baik dan hanya 9,67\% (3 siswa) saja yang memperoleh predikat sangat baik. Kriteria yang ditetapkan oleh guru adalah siswa mampu bertanya dengan frekuensi 1-3 dalam setiap kegiatan pembelajaran. Sehingga dalam setiap pembelajaran pada siklus pertama akan menghasilkan sekitar 3 kali jumlah siswa.
Refleksi dari kegiatan pelaksanaan implementasi model kooperatif tipe pair check adalah pada aktivitas guru saat menjelaskan tentang model pair check berpasangan kepada siswa. Penjelasan sudah dilaksanakan tetapi masih banyak siswa yang belum mengerti, sehingga timbul banyak pertanyaan bagaimana cara bermain dalam kegiatan tersebut. Kemungkinan hal itu dapat terjadi karena ketika guru menjelaskan siswa yang tidak paham tidak bertanya. Berdasarkan analisis data lembar observasi guru (LOG) dan lembar observasi siswa (LOS), lembar observasi keterampilan bertanya produktif, dan catatan di lapangan secara umum, penerapan model kooperatif tipe pair check pada siklus 1 ini masih ada permasalahan yang muncul dari guru dan sebagian dari peserta didik. Permasalahan yang dihadapi antara lain: (1) Guru sudah menjelaskan konsep pembelajaran dengan baik, tetapi beberapa siswa masih belum memahami penjelasan tersebut; (2) Guru sudah memberi tugas kepada siswa agar membentuk kelompok berpasangan, ternyata siswa selalu memilih teman satu bangku; (3) Guru menyampaikan tujuan pembelajaran dan menjelaskan tentang model kooperatif tipe pair check, termasuk didalamnya ketika siswa harus menentukan peran sebagai pelatih atau partner. Ternyata sebagian besar siswa masih tidak mengerti bagaimana cara bermain dalam kegiatan ini; (4) Guru menjelaskan tentang tingkatan kognitif dalam membuat pertanyaan, tetapi banyak siswa yang belum memahami; (5) Guru menjelaskan garis besar cara membaca produktif, tetapi siswa kurang tepat dalam menemukan intisari bacaan atau teks; (6) Guru belum menyimpulkan hasil kegiatan tanya jawab yang dilakukan; (7) Guru belum memberikan evaluasi terhadap keterlaksanaan kegiatan tanya jawab tentang pertanyaan produktif kepada siswa dan guru tidak melakukan tanya jawab.

Berdasarkan permasalahan tersebut maka, peneliti akan melakukan perbaikan di siklus 2 pada aktivitas guru dalam pembelajaran sebagai berikut: (1) Guru menjelaskan konsep lebih 
jelas dan rinci, jika perlu disampaikan berulangulang; (2) Guru membagi siswa secara acak (homogen) dalam berkelompok dan berpasangan; (3) Guru menjelaskan kembali kepada siswa secara jelas dan rinci tentang model pembelajaran pair check, serta menayangkan melalui LCD; (4) Guru menayangkan power point tingkatan kognitif kepada siswa, dan menjelaskan kembali agar siswa paham dan dapat membuat pertanyaan secara produktif; (5) Guru kembali menjelaskan kepada siswa tentang cara membaca produktif agar intisari dari bacaan dapat tercapai; (6) Guru hendaknya selalu menyimpulkan hasil kegiatan setiap kali selesai pembelajaran; (7) Guru mengevaluasi siswa dengan melakukan tanya jawab setiap akhir pembelajaran.

Untuk perbaikan aktivitas siswa pada saat implementasi pembelajaran model pair check akan dilakukan sebagai berikut: (1) Siswa disarankan untuk berganti pasangan setiap kali pembelajaran, tidak hanya dengan teman sebangku; (2) Siswa diberikan waktu sebelum mulai implementasi model pair check untuk mencermati materi dan membaca bacaan atau teks yang diberikan guru; (3) Siswa disarankan untuk memberikan tanda (garis bawah merah atau memberi warna) pada bacaan yang merupakan intisari dari bacaan; (4) Siswa yang sudah mampu bertanya dengan sangat baik disarankan untuk membimbing teman yang belum paham; (5) Siswa dibimbing untuk mencermati hasil pertanyaan dan evaluasi guru.

Pelaksanaan siklus 2 dimulai dengan kegiatan pembelajaran model pair check yang direncanakan dengan mengacu pada langkahlangkah pada siklus 1 , tetapi lebih difokuskan pada perbaikan-perbaikan kelemahan yang ada pada aktivitas guru dan siswa. Pada tahap perencanaan di siklus 2 dengan materi pembelajaran pada unit 5 yaitu tentang postur tubuh manusia. Guru merancang kegiatan pembelajaran sebagai berikut: (1) Guru menjelaskan konsep lebih jelas dan terinci, jika perlu disampaikan berulang-ulang; (2) Guru membagi siswa secara acak (homogen) dalam berkelompok dan berpasangan; (3) Guru menjelaskan kembali kepada siswa tentang model pembelajaran pair check, secara jelas dan rinci serta menayangkan melalui LCD; (4) Guru menayangkan power point tingkatan kognitif kepada siswa, dan menjelaskan kembali agar siswa paham dan dapat membuat pertanyaan secara produktif; (5) Guru kembali menjelaskan kepada siswa tentang cara membaca produktif agar intisari dari bacaan dapat tercapai; (6) Guru menyimpulkan hasil kegiatan setiap selesai pembelajaran; (7) Guru mengevaluasi siswa dengan melakukan tanya jawab setiap akhir pembelajaran.

Pelaksanaan pembelajaran yang dilakukan pada siklus 2 adalah mengenai materi pada unit 5 tentang postur tubuh manusia. Kegiatan pembelajaran model pair check kembali dimplementasikan pada 3 (tiga) kali tatap muka sesuai dengan jumlah pertemuan yang telah direncanakan. Adapun pelaksanaannya selama 3 kali pertemuan dengan langkah-langkah yang meliputi pendahuluan, kegiatan inti dan penutup. Pendahuluan (kegiatan awal) pada pertemuan pertama guru mengucapkan salam dan membuka pelajaran dengan berdoa. Guru memeriksa presensi siswa, dan menyampaikan tujuan pembelajaran yang ingin dicapai yaitu siswa dapat menjelaskan pokok bahasan susunan kerangka tubuh manusia. Guru memotivasi siswa dengan menceritakan tentang kondisi tubuh manusia melalui power point. Selanjutnya guru memberikan informasi kegiatan yang akan dilakukan pada hari ini.

Pada kegiatan inti di siklus pertama ini guru melakukan kegiatan pembelajaran melalui beberapa tahapan antara lain: (1) Sebelum berpasangan dalam model pair check, siswa diajarkan memahami teks. Hal ini bertujuan untuk mengarahkan siswa dalam membuat pertanyaan produktif. Guru menjelaskan bahwa bagian penting pada bacaan atau teks hendaknya diberikan tanda berupa garis bawah atau stabilo warna; (2) Guru membagikan teks atau materi pelajaran, kemudian memandu siswa untuk membaca secara produktif dengan menggarisbawahi kalimat penting atau memberikan tanda merah pada intisari dari 
materi yang diberikan; (3) Guru membagi siswa dalam kelompok, dan berpasang-pasangan. Guru menentukan pasangan siswa secara homogen dan setiap pasangan dibebaskan untuk memilih hendak menjadi pelatih atau partner terlebih dahulu; (4) Selanjutnya siswa yang bertugas menjadi pelatih yang mendapat kesempatan pertama membuat pertanyaan produktif yang nanti akan dijawab oleh partner.

Jumlah pertanyaan yang dibuat minimal 3 dan mengacu pada teks yang sudah ada. Untuk lebih menggali kemampuan siswa dalam memahami bacaan atau teks guru mewajibkan siswa untuk bertanya sebanyak-banyaknya kepada partner selama waktu yang ditentukan belum habis; (5) Siswa yang berperan sebagai partner menjawab pertanyaan yang diberikan oleh pelatih, dilanjutkan pelatih mengoreksi jawaban benar; (6) Selanjutnya pasangan bertukar peran; (7) Setelah seluruh pasangan dalam kelompok menyelesaikan pekerjaan dalam membuat pertanyaan produktif dan menjawab, maka guru memberikan poin berupa nilai kepada siswa. Dilanjutkan dengan memberikan evaluasi kegiatan dan ketercapaian materi pembelajaran pada pertemuan ini.

Setelah selesai pembelajaran guru membahas dan menyimpulkan dari kegiatan yang telah dilakukan sebagai penutup. Pada pertemuan 1 di siklus 2 siswa mulai mehamai cara membaca produktif dan memahami bacaan. Sehingga tidak banyak kesulitan dalam membuat pertanyaan seperti sebelumnya. Guru memberikan evaluasi dan memberikan tugas kepada siswa. Penerapan pair check pada siklus 2 ini lebih menekankan pada perbaikanperbaikan atas kelemahan yang terjadi pada siklus 1. Hasil Pengamatan atau observasi terhadap aktivitas guru pada siklus 2 oleh kolaborator menunjukan bahwa aktivitas guru memiliki beberapa kelebihan antara lain dalam menjelaskan konsep lebih jelas dan terinci, memberikan arahan pada siswa pada saat membagi siswa berpasang-pasangan dalam kelompok. Guru menjelaskan tentang kawasan tingkatan kognitif kepada siswa dalam membuat pertanyaan. Guru juga menjelaskan teknik membaca produktif pada teks atau bacaan yang tengah dipelajari siswa. Guru memberikan poin dan reward berupa nilai kepada siswa. Berdasarkan hasil pengamatan oleh kolaborator diberikan catatan khusus tentang pelaksanaan pembelajaran di siklus 2, antara lain untuk memperjelas pemahaman siswa maka guru menanyangkan materi dan lain-lain dengan menggunakan LCD. Guru membagikan materi sehari sebelum pembelajaran. supaya siswa mempunyai cukup waktu untuk membaca secara cermat. Dalam pelaksanaannya siswa mampu membaca secara produktif dengan memberikan tanda pada bacaan. Pada saat mengevaluasi guru memberikan pertanyaan secara lisan dan mengkonfirmasi jawaban siswa.

Ada 3 aktivitas siswa yang diamati, yaitu (1) keterlaksanaan siswa dalam implementasi model pair check, (2) keterampilan bertanya produktif siswa, (3) tingkatan kognitif dari pertanyaan yang muncul dalam pembelajaran model pair check ini. Secara umum dalam mengamati keterlaksanaan siswa dalam implementasi model pair check ini siswa tidak mengalami kesulitan. Siswa mengikuti petunjuk yang telah disampaikan guru melalui power point, dengan mencari pasangan dan membagi peran dalam kegiatan. Dari lembar observasi siswa dapat disimpulkan bahwa siswa sudah terlihat perubahan dan perkembangannya dalam mengikuti model pembelajaran pair check. Siswa juga dalam memilih pasangan tidak hanya dengan teman sebangku tetapi bergantiganti secara berurutan dengan teman lain dalam kelas. Siswa dalam memahami bacaan atau teks lebih mudah karena siswa diberikan kesempatan untuk membaca lebih lama dan memberikan tanda pada bacaan. Tentu saja hal ini akan membantu siswa dalam membuat pertanyaan produktif.

Berdasarkan hasil analisis keterampilan bertanya produktif siswa Dalam mengamati keterampilan bertanya produktif siswa, ada 6 komponen yang diamati. Pada kegiatan siswa ketika mengungkapkan pertanyaan secara jelas dan singkat memperoleh skor sebesar 2,72 hal 
ini masuk dalam kriteria Baik. Siswa dalam mengungkapkan pertanyaan sudah baik, terlihat dari pertanyaan yang disampaikan secara lisan dan tertulis. Terlihat dari daftar pertanyaan yang muncul sudah mengacu pada tingkatan kognitif mengingat dan memahami. Komponen kedua yaitu pertanyaan berdasarkan acuan kegiatan atau bacaan memperoleh skor sebesar 2,72\% dalam kegiatan membaca secara produktif siswa mengalami peningkatan dari cukup menjadi baik, terutama dalam memahami teks bacaan dalam setiap pembelajaran.

Komponen ketiga yaitu memberikan kesempatan teman untuk berfikir memperoleh skor sebesar 2,52\% masuk dalam kategori baik, siswa memandu teman untuk menjawab pertanyaan secara tepat dan memberikan waktu sesuai dengan kesepakatan. Komponen keempat ada 2 yaitu (1) pertanyaan produktif yang didasari kegiatan bacaan mendapatkan skor sebesar 2,47 dalam hal ini siswa telah memahami inti teks atau bacaan yang diberikan guru untuk dapat bertanya secara produktif. Siswa cenderung membaca sepintas tanpa memahami ataupun mengingat teks tersebut. Siswa telah paham bahwa kegiatan membaca produktif akan menghasilkan pertanyaan produktif juga, (2) pertanyaan bermutu yang memunculkan beberapa alternatif jawaban memperoleh skor sebesar 2.57 hal ini masuk dalam kategori baik, dalam bertanya hasil yang dimunculkan adalah siswa telah masuk dalam ranah memahami (menyebutkan, menjelaskan), mengingat, dan mengaplikasi. Pada komponen kelima yaitu pengungkapan tertulis secara tingkatan kognitif diperoleh skor sebesar 2,57\% dalam kegiatan ini siswa sudah dalam tahap mampu memahami, mengingat, mengaplikasi teks atau bacaan yang telah dibaca sehingga mampu dibuat pertanyaan secara produktif.

Hasil analisis pengungkapan pertanyaan secara tertulis dilakukan pada saat siswa melakukan tanya jawab dengan teman menggunakan model pair check, guru meminta siswa untuk menuliskan pertanyaan yang sudah disampaikan. Hal ini dimaksudkan untuk mempermudah guru dalam mengelompokkan pertanyaan siswa kedalam 6 tingkatan kawasan kognitif. Pada siklus 2 ini guru memberikan kesempatan siswa bertanya sebanyak-banyaknya sesuai dengan bacaan atau teks materi pelajaran. Dengan ketentuan bahwa waktu disepakati, yakni selama 15 menit setiap pasangan siswa mampu menghasilkan minimal 5 pertanyaan tergantung dari kemampuan siswa dalam memahami bacaan. Pada siklus 2 pertanyaan yang ada dalam tingkatan kognitif mengingat terdapat 82 pertanyaan atau sebesar $29,3 \%$ dari seluruh pertanyaan yang muncul. Pada tingkatan kognitif memahami diperoleh 99 pertanyaan atau sebesar 33,3\%. Sedangkan pada tingkatan kognitif mengaplikasi diperoleh sebanyak $62 \%$ pertanyaan yang muncul atau sebesar 20,8\%. Dengan demikian jumlah pertanyaan produktif yang muncul dari siswa pada siklus 2 termasuk dalam kategori sangat baik.

Berdasarkan hasil analisis perolehan keterampilan bertanya produktif siswa dalam pembelajaran, dilihat dari hasil bahwa terdapat kenaikan tingkatan kognitif pemahaman siswa dalam bertanya secara produktif pada siklus 2 tidak ada siswa yang sangat kurang dalam bertanya, kemudian diperoleh $12,90 \%$ atau sebanyak 4 orang yang masih kurang dalam bertanya secara produktif. Selanjutnya diperoleh $38,70 \%$ atau sebanyak 12 orang siswa yang memperoleh predikat baik dalam bertanya secara produktif. Data selanjutnya diperoleh $48,30 \%$ atau sebanyak 15 orang siswa yang telah terampil dalam bertanya secara produktif dan memperoleh predikat sangat baik.

Hasil refleksi berdasarkan hasil analisis data yang diperoleh dari LOG (lembar observasi guru) dan LOS (lembar observasi siswa), lembar rekapitulasi daftar pertanyaan siswa, lembar observasi kemampuan bertanya produktif siswa, dan catatan di kelas pada saat pembelajaran menunjukan secara umum bahwa model kooperatif tipe pair check ini mengalami peningkatan dan perubahan pada siklus 2, terutama dalam keterampilan siswa untuk bertanya sesuai dengan bacaan atau teks. Selain itu siswa juga mengalami perubahan kualitas 
pertanyaan dari tingkatan kognitif memahami, mengingat dan mengaplikasi. Berdasarkan data hasil observasi yang diperoleh dari LOG dan LOS, lembar rekapitulasi daftar pertanyaan siswa, dan lembar observasi kemampuan bertanya produktif siswa menunjukkan bahwa terjadi perubahan dan peningkatan dalam implementasi model kooperatif tipe pair check pada mata pelajaran Anatomi dan Fisiologi dengan pokok bahasan susunan kerangka tubuh manusia di siklus 1 , dan materi postur tubuh manusia di siklus 2. Perbandingan hasil siklus 1 dan 2 lembar observasi guru dapat dilihat pada Tabel 2.

Tabel 2. Perbandingan Hasil Siklus 1 dan 2 Lembar Observasi Guru

\begin{tabular}{|c|c|c|c|c|}
\hline No & Aktivitas Guru & \multicolumn{2}{|c|}{ Keterlaksanaan } & Keterangan \\
\hline 1 & $\begin{array}{l}\text { Guru menjelaskan konsep: tujuan pembelajaran dan } \\
\text { cakupan materi pelajaran }\end{array}$ & $\mathrm{Ya}$ & $\mathrm{Ya}$ & \\
\hline 2 & $\begin{array}{l}\text { Guru memberikan tugas kepada siswa agar membentuk } \\
\text { kelompok berpasangan }\end{array}$ & Ya & Ya & \\
\hline 3 & $\begin{array}{l}\text { Guru memberi arahan akan peran dari setiap anggota } \\
\text { kelompok: seorang disebut partner dan seorang yang lain } \\
\text { disebut pelatih }\end{array}$ & Ya & $\mathrm{Ya}$ & \\
\hline 4 & $\begin{array}{l}\text { Guru menjelaskan bahwa tugas pelatih memberikan } \\
\text { pertanyaan, dan partner menjawab sesuai isi bacaan }\end{array}$ & Ya & $\mathrm{Ya}$ & \\
\hline 5 & $\begin{array}{l}\text { Guru menjelaskan pula bahwa pelatih wajib mengecek } \\
\text { jawaban dan partner boleh mempertahankan pendapatnya }\end{array}$ & Ya & $\mathrm{Ya}$ & \\
\hline 6 & $\begin{array}{l}\text { Guru menjelaskan setelah bertanya jawab untuk beberapa } \\
\text { lama, siswa beralih peran yang semula pelatih beralih } \\
\text { sebagai partner kemudian melakukan kegiatan tanya jawab }\end{array}$ & Ya & Ya & \\
\hline 7 & $\begin{array}{l}\text { Guru menyimpulkan hasil kegiatan tanya jawab yang } \\
\text { dilakukan setiap pasangan }\end{array}$ & Tidak & $\mathrm{Ya}$ & \\
\hline 8 & $\begin{array}{l}\text { Guru memberikan evaluasi terhadap keterlaksanaan } \\
\text { kegiatan tanya jawab }\end{array}$ & Tidak & Ya & \\
\hline 9 & Guru memberikan point/reward & Ya & Ya & \\
\hline
\end{tabular}

Berdasarkan Tabel 2 di atas terlihat bahwa terdapat perubahan peningkatan hasil terhadap tindakan guru di siklus 1 dan siklus 2 . Jika dilihat dari hasil konsistensi pada tiap siklus menunjukkan bahwa pada aktivitas guru: (1) penjelasan guru akan konsep, tujuan pembelajaran dan cakupan materi pelajaran telah dilaksanakan dengan tepat sesuai dengan sintak pada model pair check; (2) pemberian tugas kepada siswa agar membentuk kelompok telah dilakukan. Pada awal praktek siswa lebih memilih teman sebangku daripada dengan teman lain. Dengan diberikan pemahaman dan bantuan guru siswa memilih teman untuk berpasangan secara bergantian; (3) Guru memberikan arahan akan peran dari setiap anggota kelompok yaitu seorang disebut partner dan seorang yang lain disebut pelatih. Guru memandu dan mengarahkan siswa, selain itu guru juga menayangkan urutan pembelajaran di power point sehingga siswa lebih mudah dalam memahami; (4) guru menjelaskan bahwa tugas pelatih memberikan pertanyaan, dan partner menjawab sesuai isi bacaan, pada tahap ini berjalan lancar, walaupun pada awalnya banyak kendala yang dialami oleh siswa karena siswa belum memahami sepenuhnya cara membaca secara produktif. Dengan penjelasan guru di siklus 2 maka hal tersebut tidak terjadi kembali; (5) guru menjelaskan pula bahwa pelatih wajib memeriksa jawaban dari partner dan partner boleh mempertahankan pendapatnya; (6) guru menjelaskan setelah bertanya jawab untuk beberapa lama, siswa beralih peran yang semula pelatih beralih menjadi partner kemudian melakukan kegiatan tanya jawab, kegiatan tersebut dipantau guru dengan mendokumentasikan. Setiap pertanyaan siswa yang muncul wajib dituliskan dikertas; (7) guru menyimpulkan hasil kegiatan tanya jawab yang dilakukan setiap pasangan, awalnya guru lupa untuk menyimpulkan hasil pembelajaran pada 
saat itu selanjutnya guru sudah melakukannya; (8) guru memberikan evaluasi terhadap keterlaksanaan kegiatan tanya jawab, di siklus 1 hal ini belum dilakukan, pada pertemuan selanjutnya guru memberikan evaluasi dengan lisan, dan tertulis (paper based test); (9) guru memberikan poin atau reward, reward yang diberikan berupa nilai atau skor pada masing masing siswa dan nilai untuk pasangan. Gambar 1 menunjukan rerata aktivitas guru di siklus 1 dan siklus 2 .
Gambar 1 menjelaskan hasil analisis LOG dalam keterlaksanaan implementasi model pair check yang dilaksanakan selama 2 siklus. Pada siklus pertama diperoleh sebanyak 7 (ya), sehingga digambarkan pada diagram berupa angka 7, dan pada siklus kedua diperoleh sebanyak 9 (ya) sehingga digambarkan pada diagram angka 9. Tabel 3 berikut menunjukkan hasil analisis pengungkapan pertanyaan secara tertulis.

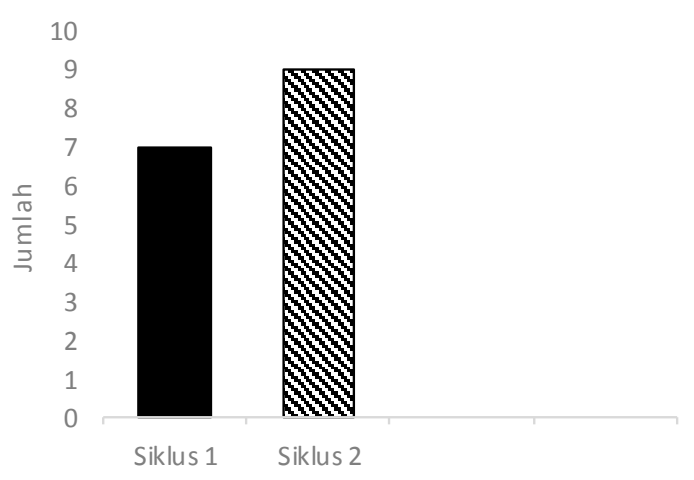

Gambar 1. Rerata Aktivitas Guru

Tabel 3. Perbandingan Hasil Siklus 1 dan Siklus 2 Lembar Observasi Siswa (LOS) Keterlaksanaan Siswa dalam Implementasi Model Pair Check

\begin{tabular}{|c|c|c|c|c|}
\hline \multirow[t]{2}{*}{ No } & \multirow[t]{2}{*}{ Aktivitas Siswa } & \multicolumn{2}{|c|}{ Keterlaksanaan } & \multirow[t]{2}{*}{ Keterangan } \\
\hline & & Siklus 1 & Siklus 2 & \\
\hline 1 & $\begin{array}{l}\text { Siswa melaksanakan tugas untuk berpasang-pasangan } \\
\text { (berdua-dua) dengan posisi saling berhadapan }\end{array}$ & $\sqrt{ }$ & $\sqrt{ }$ & $\begin{array}{l}\text { Siswa lebih } \\
\text { memilih teman } \\
\text { sebangku }\end{array}$ \\
\hline 2 & $\begin{array}{l}\text { Siswa berbagi peran, seorang sebagai pelatih dan } \\
\text { yang lain partner }\end{array}$ & $\sqrt{ }$ & $\sqrt{ }$ & \\
\hline 3 & $\begin{array}{l}\text { Siswa yang berperan sebagai pelatih mengajukan } \\
\text { pertanyaan-pertanyaan mengenai isi bacaan dan } \\
\text { partner menjawab pertanyaan tersebut }\end{array}$ & $\sqrt{ }$ & $\sqrt{ }$ & $\begin{array}{l}\text { Siswa belum } \\
\text { sepenuhnya } \\
\text { memahami isi } \\
\text { bacaan atau teks }\end{array}$ \\
\hline 4 & $\begin{array}{l}\text { Siswa yang berperan sebagai pelatih, mengecek } \\
\text { jawaban partner }\end{array}$ & $\sqrt{ }$ & $\sqrt{ }$ & \\
\hline 5 & $\begin{array}{l}\text { Masing-masing pasangan berganti peran, yang } \\
\text { semula sebagai pelatih berganti sebagai partner dan } \\
\text { sebaliknya }\end{array}$ & $\sqrt{ }$ & $\sqrt{ }$ & \\
\hline 6 & $\begin{array}{l}\text { Siswa mengakhiri kegiatan tanya jawab (pair check) } \\
\text { dengan memberikan poin untuk pasangannya }\end{array}$ & $\sqrt{ }$ & $\sqrt{ }$ & \\
\hline
\end{tabular}

Jika diamati dari Tabel 3 di atas keterlaksanaan siswa dalam mengikuti model pembelajaran pair check dirangkum sebagai berikut: (1) siswa melaksanakan tugas untuk berpasang-pasangan (berdua-dua) dengan posisi saling berhadapan, kegiatan ini berlangsung selama siswa melakukan tanya jawab dengan pasangannya, terkadang jika siswa bosan duduk berhadapan siswa dapat membuat formasi lain yang lebih nyaman; (2) siswa berbagi peran, seorang sebagai pelatih dan yang lain partner, siswa dengan senang hati bergantian peran, 
yang menjadi pelatih pertama adalah siswa yang lebih menguasai materi, selanjutnya dilaksanakan secara bergantian; (3) siswa yang berperan sebagai pelatih mengajukan pertanyaanpertanyaan mengenai isi bacaan dan partner menjawab pertanyaan tersebut, pada kegiatan ini siswa harus sudah memahami isi bacaan atau teks yang telah diberikan sehingga dalam membuat pertanyaan dan menjawab pertanyaan menjadi tepat sesuai dengan tingkatan kognitif yang disarankan; (4) siswa yang berperan sebagai pelatih memeriksa jawaban partner. Pelatih memegang bacaan sebagai acuan dalam memeriksa atau mengoreksi jawaban pasangannya; (5) masing-masing pasangan berganti peran, yang semula sebagai pelatih berganti sebagai partner dan sebaliknya; (6) siswa mengakhiri kegiatan tanya jawab (pair check) dengan memberikan poin untuk pasangannya, siswa memberikan poin 2 untuk jawaban benar, poin 1 untuk jawaban yang 13 hampir benar dan 0 untuk jawaban salah. Dari penjabaran data di atas dapat dikatakan bahwa keterlaksanaan siswa dalam implementasi model pair check tidak mengalami perubahan secara signifikan tetapi lebih kepada perubahan tingkah laku berdasarkan pengamatan guru ketika pembelajaran. Hasil analisis observasi keterampilan bertanya produktif siswa pada siklus 1 dan siklus 2 dijelaskan pada Tabel 4 .

Tabel 4. Hasil Analisis Observasi Keterampilan Bertanya Produktif Siswa Pada Siklus 1 dan Siklus 2

\begin{tabular}{|c|c|c|c|c|}
\hline \multirow[t]{2}{*}{ No } & \multirow[t]{2}{*}{ Komponen } & \multicolumn{2}{|c|}{ Skor yang Diperoleh } & \multirow[t]{2}{*}{ Keterangan } \\
\hline & & Rerata Siklus 1 & Rerata Siklus 2 & \\
\hline 1 & $\begin{array}{l}\begin{array}{l}\text { Pengungkapan } \\
\text { singkat }\end{array} \\
\text { pertanyaan secara jelas dan }\end{array}$ & 1,77 & 2,72 & Meningkat \\
\hline 2 & Pertanyaan berdasarkan acuan kegiatan/bacaan & 1,75 & 2,72 & Meningkat \\
\hline 3 & $\begin{array}{l}\text { Memberikan kesempatan temannya untuk } \\
\text { berfikir }\end{array}$ & 1,95 & 2,52 & Meningkat \\
\hline \multirow[t]{2}{*}{4} & $\begin{array}{l}\text { Hasil pertanyaan yang muncul } \\
\text { a. Pertanyaan produktif yang didasari kegiatan } \\
\text { bacaan }\end{array}$ & 1,6 & 2,47 & Meningkat \\
\hline & $\begin{array}{l}\text { b. Pertanyaan bermutu yang memunculkan } \\
\text { beberapa alternatif jawaban }\end{array}$ & 1,45 & 2,36 & Meningkat \\
\hline \multirow[t]{4}{*}{5} & $\begin{array}{l}\text { Pengungkapan tertulis pertanyaan secara } \\
\text { tingkatan kognitif } \\
\text { a. Mengingat } \\
\text { b. Memahami } \\
\text { c. Menerapkan } \\
\text { d. Menganalisis } \\
\text { e. Mengevaluasi } \\
\text { f. Berkreasi }\end{array}$ & 1,77 & 2,57 & Meningkat \\
\hline & Jumlah Skor & 10,29 & 15,36 & \\
\hline & Rerata & 1,72 & 2,56 & \\
\hline & Kriteria & Cukup & Baik & \\
\hline
\end{tabular}

Rerata hasil dari analisis observasi siklus 1 dan siklus 2 dijelaskan pada Gambar 2 keterampilan bertanya produktif siswa pada sebagai berikut.

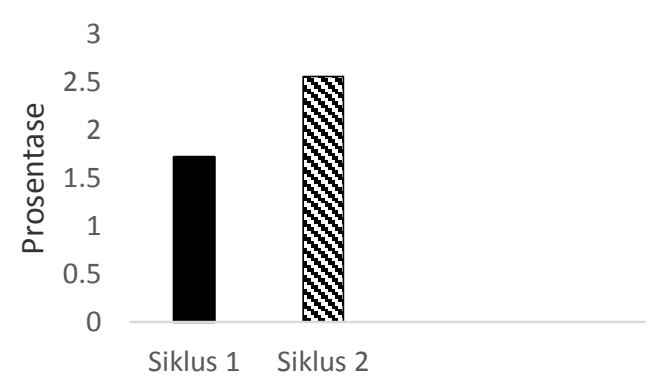

Gambar 2. Hasil Analisis Observasi

Keterampilan Bertanya Produktif Siswa 
Data pada Gambar 2 menunjukan hasil analisis observasi keterampilan bertanya produktif siswa pada siklus 1 dan siklus 2 . Siklus pertama sebesar $1,72 \%$ dan siklus 2 sebesar 2,56\%. Ada peningkatan yang signifikan dari siklus 1 ke siklus 2 sebesar $0,84 \%$. Hasil analisis pengungkapan pertanyaan secara tingkatan kognitif dapat dilihat pada Tabel 5 sebagai berikut.

Tabel 5. Hasil Analisis Pengungkapan Pertanyaan secara Tingkatan Kognitif

\begin{tabular}{|c|c|c|c|c|c|}
\hline \multirow[t]{2}{*}{ No } & & \multirow[t]{2}{*}{ Tingkatan Kognitif } & \multicolumn{2}{|c|}{$\begin{array}{c}\text { Jumlah Pertanyaan yang } \\
\text { Muncul }\end{array}$} & \multirow[t]{2}{*}{ Keterangan } \\
\hline & & & Siklus 1 & Siklus 2 & \\
\hline 1 & Mengingat & & 49 kali & 82 kali & Meningkat \\
\hline 2 & Memahami & & 81 kali & 99 kali & Meningkat \\
\hline 3 & Mengaplikasi & & 33 kali & 62 kali & Meningkat \\
\hline 4 & Menerapkan & & - & - & - \\
\hline 5 & Menganalisis & & - & - & - \\
\hline \multirow[t]{3}{*}{6} & Mengkreasi & & - & - & - \\
\hline & & Jumlah & 163 kali & 243 kali & \\
\hline & & Kriteria & Baik & Sangat Baik & \\
\hline
\end{tabular}

Dari Tabel 5 di atas terlihat adanya peningkatan frekuensi jumlah pengungkapan pertanyaan siswa secara tingkatan kognitif. Hal ini menunjukkan bahwa selama 2 siklus terjadi perubahan pada keterampilan siswa bertanya produktif berdasarkan bacaan atau teks. Berikut adalah diagram hasil analisis pengungkapan pertanyaan secara tingkatan kognitif dijelaskan pada Gambar 3.

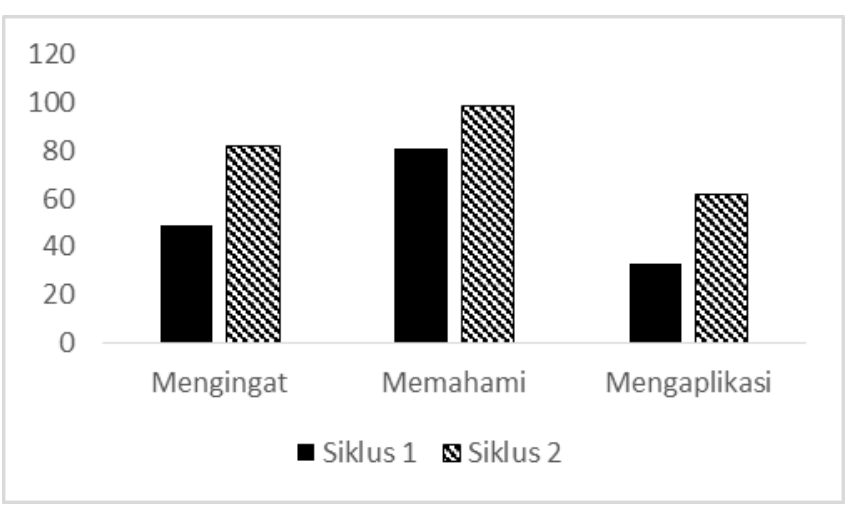

Gambar 3. Hasil Analisis Pengungkapan Pertanyaan secara Tingkatan Kognitif

Gambar 3 mendeskripsikan hasil analisis pengungkapan pertanyaan secara tingkatan kognitif, yaitu pada tingkatan kognitif mengingat di siklus 1 diperoleh frekuensi sebanyak 49 kali dan meningkat menjadi 82 kali pada siklus 2 . Sedangkan pada tingkatan kognitif memahami pada siklus 1 diperoleh sebanyak 81 kali dan meningkat menjadi 99 kali pada siklus 2. Pada siklus 1 diperoleh frekuensi sebanyak 33 kali dan meningkat menjadi 62 kali pada siklus 2, pada tingkatan kognitif mengaplikasi. Dengan demikian selama 2 siklus siswa mengalami perkembangan, peningkatan jumlah frekwensi dalam bertanya hal ini dimaknai sebagai pembangun keterampilan bertanya produktif.

\section{SIMPULAN}

Dalam proses membangun keterampilan bertanya produktif siswa pada mata pelajaran anatomi terdapat 9 tahapan antara lain: menjelaskan konsep, membagi siswa dalam 
kelompok, membagikan teks, melaksanakan pair check, siswa bertukar peran, mencocokkan jawaban, membimbing dan mengarahkan, mengecek jawaban benar, dan mendapatkan reward. Kondisi awal yang menunjukkan siswa ketika mengungkapkan pertanyaan secara singkat dan jelas memperoleh kriteria cukup pada 6 komponen yang diamati. Pada akhir kegiatan (siklus 2) mengalami peningkatan dengan memperoleh kriteria baik. Hal ini terlihat dari frekuensi siswa dalam bertanya mengalami peningkatan, dan mampu membaca secara produktif sesuai dengan teks atau bacaan yang diberikan oleh guru. Sehingga indikator kinerja yaitu sebesar 70\% dari jumlah siswa (sebesar 22 orang) di kelas X TK 2 terampil bertanya produktif di siklus 1 tercapai dengan memperoleh kriteria baik $(61,3 \%)$ dan kriteria sangat baik (9,67\%).Terdapat pengembangan pada keterampilan bertanya secara produktif siswa dari siklus 1 ke siklus 2, yakni dengan adanya perbaikan-perbaikan di siklus 2 membuat terjadinya perubahan pada 6 kompenen yang diamati. Hasil yang diperoleh pada siklus 2 yakni sebanyak 12 orang $(38,70 \%)$ siswa memperoleh predikat baik dalam bertanya secara produktif, dan sebanyak 15 orang $(48,30 \%)$ memperoleh predikat sangat baik dalam bertanya produktif sehingga indikator kinerja pada siklus 2 sebesar $80 \%$ dari jumlah siswa dikelas terampil bertanya produktif pada mata pelajaran Anatomi dan Fisiologi dapat tercapai.

\section{DAFTAR RUJUKAN}

Anita Lie. 2002. Cooperative Learning (Memperaktikan Cooperative Learning di Ruang-ruang Kelas). Jakarta: PT Gramedia Widiasarana

Depdiknas. 2003. Kegiatan Belajar Mengajar Efektif. Jakarta: Depdiknas

Hassoubah, Izhab Zaleha. 2004. Developing Creatif and Critical Thinking Skill (Cara Berpikir Kreatif dan Kritis). Nuansa: Bandung

Huda, Miftahul.2003. Model- model Pengajaran dan Pembelajaran. Yogyakarta: Pustaka Pelajar

Nur dan Agus G. Senduk. 2003. Pembelajaran Kontekstual dan Penerapannya dalam $K B K$. Malang: UNM 